\title{
DEVELOPMENT OF CURRICULUM BASED ON THE LOCAL WISDOM
}

\section{Septiana Agustin}

Sebelas Maret University

septiana.agustin@gmail.com

\section{Article History}

accepted 09/07/2018

approved 01/08/2018

published 17/09/2018

\section{Keywords}

development, curriculum, local wisdom, natural resources, human resources

\begin{abstract}
This study aims to develop the curriculum of Bejalen Public Elementary School in Semarang Regency based on the values of local wisdom. The development of this curriculum is based on the characters and resources in the local area, both natural and human resources. This type of research is descriptive qualitative with data collection techniques through observation, interviews, and FGD (Forum Group Discussion). Observations show that local areas have maritime potential as natural resources. Thus, most of the livelihoods of Bejalen Elementary School students are fishermen. The results of interviews with local residents include utilization of natural resources and empowerment of human resources. The results of the FGD with the local district staff members produced data that the local area had become one of the tourist areas in Semarang Regency called Pelangi Tourism Village. All of this data is the material for developing the curriculum of Bejalen Public Elementary School. The results of this study explain that the curriculum development of Bejalen Public Elementary School in Semarang Regency is based on the values of local wisdom which includes the cultivation of natural resources and the empowerment of human resources. The recommendation for further research is research on developing elementary school curriculum based on local wisdom in other schools.
\end{abstract}

Social, Humanities, and Education Studies (SHEs): Conference Series https://jurnal.uns.ac.id/shes
p-ISSN 2620-9284

e-ISSN 2620-9292 


\section{PENDAHULUAN}

Dewasa ini, diterapkan sistem pendidikan abad 21 yang sudah disetarakan dengan ranah perkembangan anak secara umum (Howard, P. et, al. 2018). Pendidikan abad 21 menuntut adanya pendalaman materi yang terintegrasi dengan penguatan pendidikan karakter. Penguatan pendidikan karakter berisi tentang nilai-nilai karakter yang disesuaikan dengan tugas maupun tahap perkembangan anak (Peraturan Presiden Nomor 87 Tahun 2017). Secara serentak setiap satuan pendidikan di seluruh Indonesia menerapkan penguatan pendidikan karakter mulai dari jenjang sekolah dasar, menengah, hingga atas.

Pengembangan kurikulum secara umum mengacu pada pedoman pemerintah. Beberapa kurikulum yang sudah pernah diterapkan di sistem pendidikan Indonesia, antara lain: Kurikulum 1994, Kurikulum Berbasis Kompetensi (Tahun 2004), Kurikulum Tingkat Satuan Pendidikan (2006), dan yang sekarang ini dijalankan adalah Kurikulum 2013. Masing-masing kurikulum memiliki tujuan, dasar, prinsip, dan metode yang berbeda-beda. Namun demikian, pencapaian akhir yang diharapkan adalah sama, yaitu mencetak generasi bangsa yang cerdas dan berkualitas. Salah satu pembaharuan dalam Kurkulum 2013 yang saat ini diterapkan adalah adanya nilai-nilai karakter yang sudah terintegrasi di dalam buku guru dan buku siswa. Rencana pembelajaran harian sudah dilengkapi dengan pemetaan mata pelajaran, pembagian materi ajar, metode, media, alat peraga, soal evaluasi, sistem evaluasi, serta rubrik penilaian.

Kurikulum merupakan suatu rencana yang disusun untuk melancarkan proses belajar mengajar di bawah bimbingan dan tanggung jawab sekolah atau lembaga pendidikan beserta staf pengajarnya (Nasution, 2008). Isi kurikulum meliputi program belajar bagi siswa yang disusun secara sistematis dan logis, guna mencapai tujuan pendidikan. Kurikulum juga merupakan program dan pengalaman belajar serta hasilhasil belajar yang diformulasikan melalui pengetahuan dan kegiatan yang tersusun secara sistematis, diberikan kepada siswa di bawah tanggung jawab sekolah untuk membantu pertumbuhan dan perkembangan pribadi serta kompetensi sosial anak didik (Sudjana, 2005). Dengan demikian dapat dipahami bahwa kurikulum merupakan sebuah paket program yang dirancang untuk memenuhi kapasitas bagi guru atau staf pengajar yang ada di sekolah.

Ditegaskan kembali dalam Undang-Undang Republik Indonesia Nomor 20 Tahun 2003 tentang Sistem Pendidikan Nasional Pasal 1 ayat 9 menjelaskan bahwa kurikulum adalah seperangkat rencana dan pengaturan mengenai tujuan, isi, tambahan pelajaran, serta cara yang digunakan sebagai pedoman penyelenggaraan kegiatan pembelajaran untuk mencapai tujuan pendidikan tertentu. Dengan mengacu pada sistem pendidikan nasional ini, maka setiap satuan pendidikan diberi wewenang atau hak otonomi untuk mengembangkan kurikulum sesuai dengan karakteristik peserta didik dan daerah setempat. Segala sumber daya alam yang dimiliki oleh daerah lokal, dapat dijadikan sebagai dasar pengembangan kurikulum yang nantinya bersifat kontekstual. Tujuannya adalah menjadikan para peserta didik berkembang dengan potensi mereka, serta memberi bekal kepada mereka untuk memiliki life skill. Sehingga, mereka memiliki pola pikir yang mampu memotivasi diri untuk terus menjadi lebih baik (Waruwu, 2010).

Kurikulum yang dikembangkan oleh SD Negeri Bejalen berbasis pada kearifan lokal. Sebuah kurikulum yang didalamnya ditambah muatan terkait pemberdayaan semuber daya yang ada di daerah setempat. Desa belajen memiliki beberapa hasil sumber daya yang dapat dijadikan sebagai tambahan dalam muatan lokal. Hasil sumber daya alam yang dapat dikembangkan dalam kurikulum SD Negeri Bejalen, antara lain: pembuatan telur asin (berasal dari peternak itik), pembuatan nugget betutu (berasal dari ikan betutu yang didapatkan dari Rawa Pening, pembuatan minuman sari 
genjer (berasal dari sayur genjer yang ada di perairan sekitar sawah), dan pembuatan dodol cikru (berasal dari biji bunga teratai yang dikeringkan).

Setiap daerah pasti memiliki ciri khas tersendiri, baik dari segi sumber daya alam, jenis mata pencaharian, tata nilai, tradisi, maupun adat istiadat yang dianut. Beragam ciri khas sebuah daerah berpotensi untuk menjadi sebuah budaya yang bernilai tinggi. Suatu gagasan bijaksana, bernilai baik, sudah tertanam, dan diikuti oleh anggota masyarakatnya disebut kearifan lokal (Baedowi, 2015). Melalui adanya konsep tentang pentingnya kearifan lokal, maka diharapkan setiap satuan pendidikan dapat mengembangkan kurikulum yang tidak hanya didasarkan pada perkembangan IPTEK (Ilmu Pengetahuan dan Teknologi) tetapi juga nilai-nilai lokal yang dapat disesuaikan dengan pengiringan pembelajaran abad 21 .

Pembelajaran biasanya bersifat kontekstual, sehingga metode pengajarannya tersaji secara langsung dengan melibatkan peserta didik (Poerwati, 2013). Pembelajaran yang mengintegrasikan unsur-unsur alam atau hayati, akan lebih cepat tertangkap dan bermakna bagi para peserta didik. Oleh karena itu, penelitian ini menggali tentang kompetensi dan potensi peserta didik untuk dapat dikolaborasikan dengan kegiatan-kegiatan yang memanfaatkan sumber daya alam lokal. Penelitian ini berfokus pada pengembangan kurikulum SD Negeri Bejalen yang berbasis pada kearifan lokal.

\section{METODE}

Jenis penelitian ini adalah deskriptif kualitatif dengan teknik pengumpulan data melalui observasi di SD Negeri Bejalen, wawancara dengan penduduk desa Bejalen, dan FGD (Forum Group Discussion) dengan kepala sekolah, guru-guru, dan komite SD Negeri Bejalen, serta dengan melibatkan tokoh masyarakat, dan pemangku jabatan desa.

\section{HASIL DAN PEMBAHASAN}

Desa wisata Bejalen memiliki sebuah perairan yang menjadi sumber daya alam bagi penduduk setempat. Perairan ini dikenal dengan nama Rawa Pening. Sehingga, sebagian besar mata pencaharian wali murid SD Negeri Bejalen adalah sebagai nelayan. Dapat dilihat pada Tabel 1.

Tabel 1. Hasil Observasi Mata Pencaharian Wali Murid SDN Bejalen

\begin{tabular}{cccccc}
\hline Petani & Peternak & Nelayan & Buruh & Pedagang & TKI \\
\hline $12.63 \%$ & $13.63 \%$ & $35.77 \%$ & $10.43 \%$ & $11.92 \%$ & $15.59 \%$ \\
\hline
\end{tabular}

*jumlah keseluruhan siswa adalah 109 anak.

Kurikulum yang dikembangkan oleh SD Negeri Bejalen berbasis pada kearifan lokal. Sebuah kurikulum yang didalamnya ditambah muatan terkait pemberdayaan sember daya yang ada di daerah setempat. Desa Bejalen memiliki beberapa hasil sumber daya yang dapat dijadikan sebagai tambahan dalam muatan lokal. Hasil sumber daya alam yang dapat dikembangkan dalam kurikulum SD Negeri Bejalen, antara lain: pembuatan telur asin (berasal dari peternak itik), pembuatan nugget betutu (berasal dari ikan betutu yang didapatkan dari Rawa Pening, pembuatan minuman sari genjer (berasal dari sayur genjer yang ada di perairan sekitar sawah dan rawa), serta pembuatan dodol cikru (berasal dari biji bunga teratai yang dikeringkan). Beberapa prestasi yang pernah diraih oleh SD Negeri Bejalen terkait pengembangan kurikulum berdasarkan kearifan lokal. Dapat dilihat pada Tabel 2.

Tabel 2. Prestasi SD Negeri Bejalen dalam memberdayakan Sumber Daya Alam

$\begin{array}{cccc}\text { Tahun } & 2013 & 2014 & 2015 \\ \text { Produk } & \text { Dodol Cikru } & \text { Nugget Betutu } & \text { Squash Genjer }\end{array}$




\begin{tabular}{|c|c|c|c|}
\hline Prestasi & $\begin{array}{c}\text { Juara Harapan II } \\
\text { InMatra }\end{array}$ & Juara I InMatra & Juara I InMatra \\
\hline
\end{tabular}

Pengembangan kurikulum berbasis kearifan lokal tidak hanya bersumber dari sumber daya alam yang ada di desa Bejalen, namun juga dari karakteristik SD Negeri Bejalen itu sendiri. Kriteria sekolah yang baik adalah sekolah yang memenuhi Standar Nasional Pendidikan (SNP). Sekolah yang memenuhi SNP adalah sekolah yang memiliki sistem, fasilitas, tenaga kependidikan, strategi, kompetensi lulusan, dan sarana prasarana yang memadai untuk jalannya kegiatan pembelajaran di satuan pendidikan. Reputasi sekolah yang baik dapat terlihat dari kualitas lulusan yang dihasilkan. Dapat dilihat pada Tabel 3.

Tabel 3. Data Kelulusan Siswa SD Negeri Bejalen

\begin{tabular}{cccccc}
\hline $\begin{array}{c}\text { Tahun } \\
\text { Ajaran }\end{array}$ & $\mathbf{2 0 1 3 / 2 0 1 4}$ & $\mathbf{2 0 1 4 / 2 0 1 5}$ & $\mathbf{2 0 1 5 / 2 0 1 6}$ & $\mathbf{2 0 1 6 / 2 0 1 7}$ & $\mathbf{2 0 1 7 / 2 0 1 8}$ \\
\hline Kelulusan & $100 \%$ & $100 \%$ & $100 \%$ & $100 \%$ & $100 \%$ \\
\hline
\end{tabular}

Berdasarkan Peraturan Pemerintah Nomor 19 Tahun 2005 dijelaskan bahwa ada 8 standar nasional pendidikan yaitu pada BAB II pasal 2 ayat 1. Kedelapan standar tersebut meliputi standar isi, standar proses, standar kompetensi lulusan, standar pendidik dan tenaga kependidikan, standar sarana prasarana, standar pengelolaan, standar pembiayaan serta standar penilaian pendidikan. Mencermati hal tersebut, maka SDN Bejalen melakukan sebuah analisis konteks dengan menggunakan metode analisis SWOT (kekuatan, kelemahan, tantangan, dan peluang) untuk 4 standar. Dapat dilihat pada Tabel 4.

Tabel 4. Hasil Analisis Konteks SD Negeri Bejalen menggunakan Analisis SWOT

\begin{tabular}{|c|c|c|c|c|}
\hline Standar & Kekuatan & Kelemahan & Peluang & Ancaman \\
\hline $\begin{array}{l}\text { Tenaga } \\
\text { Pendidik }\end{array}$ & $\begin{array}{l}\text { Sebanyak 98\% } \\
\text { guru } \\
\text { berkualifikasi } \\
\text { S1 }\end{array}$ & $\begin{array}{l}\text { Metode } \\
\text { mengajar masih } \\
\text { kurang } \\
\text { berinovasi }\end{array}$ & $\begin{array}{l}\text { Lebih dari } \\
\text { separuh guru } \\
\text { sudah memiliki } \\
\text { sertifikat pendidik }\end{array}$ & $\begin{array}{l}\text { Kemajuan IPTEK } \\
\text { yang berkembang } \\
\text { dengan pesat }\end{array}$ \\
\hline $\begin{array}{l}\text { Kompetensi } \\
\text { Lulusan }\end{array}$ & $\begin{array}{l}\text { Selama kurun } \\
\text { waktu } 5 \text { tahun } \\
\text { lulus } 100 \%\end{array}$ & $\begin{array}{l}\text { Rata-rata masih } \\
\text { belum maksimal }\end{array}$ & $\begin{array}{l}\text { Pernah masuk } 5 \\
\text { besar se- } \\
\text { kecamatan }\end{array}$ & $\begin{array}{l}\text { Semakin ketat } \\
\text { persaingan } \\
\text { dengan sekolah } \\
\text { yang lain }\end{array}$ \\
\hline $\begin{array}{l}\text { Sarana } \\
\text { Prasarana }\end{array}$ & $\begin{array}{l}\text { Ruang kelas, } \\
\text { lab komputer, } \\
\text { dan perpus, } \\
\text { memadai. }\end{array}$ & $\begin{array}{l}\text { Alat peraga yang } \\
\text { dibutuhkan untuk } \\
\text { mapel IPA } \\
\text { kurang lengkap }\end{array}$ & $\begin{array}{l}\text { Banyak donatur } \\
\text { yang memberi } \\
\text { bantuan. }\end{array}$ & $\begin{array}{l}\text { Di tengah desa } \\
\text { Bejalen dilintasi } \\
\text { jalan lingkar, } \\
\text { sehingga anak- } \\
\text { anak perlu berhati- } \\
\text { hati. }\end{array}$ \\
\hline Pembiayaan & $\begin{array}{l}\text { Bantuan dari } \\
\text { BOS, BOSDA, } \\
\text { dan bantah } \\
\text { yang lain. }\end{array}$ & $\begin{array}{l}\text { Tidak ada } \\
\text { kewenangan } \\
\text { untuk } \\
\text { menghimpun } \\
\text { dana dari orang } \\
\text { tua/ wali murid } \\
\text { untuk kebutuhan } \\
\text { operasional } \\
\text { pendidikan. }\end{array}$ & $\begin{array}{l}\text { Banyak alumni } \\
\text { yang memberi } \\
\text { bantuan. }\end{array}$ & $\begin{array}{l}\text { Tidak tampil di } \\
\text { ajang perlombaan } \\
\text { karena tidak } \\
\text { mampu membayar } \\
\text { pelatih. }\end{array}$ \\
\hline
\end{tabular}


Hasil observasi menunjukkan bahwa daerah lokal memiliki potensi maritim sebagai sumber daya alam. Sehingga, mata pencaharian penduduk setempat adalah para pencari ikan. Hasil wawancara dengan penduduk daerah lokal antara lain pemanfaatan hasil sumber daya alam, serta pemberdayaan sumber daya manusia. Hasil FGD dengan anggota pegawai kelurahan setempat menghasilkan data bahwa daerah setempat telah menjadi salah satu daerah wisata yang ada di Kabupaten Semarang yang disebut dengan Desa Wisata Pelangi. Semua data ini menjadi bahan pengembangan kurikulum SD Negeri Bejalen. Hasil penelitian ini menjelaskan bahwa pengembangan kurikulum SD Negeri Bejalen Kabupaten Semarang didasarkan pada nilai-nilai kearifan lokal yang meliputi pembudidayaan sumber daya alam dan pemberdayaan sumber daya manusia.

\section{DAFTAR PUSTAKA}

Baedowi, A. (2015). Calak Edu 4: Esai-Esai Pendidikan 2002-2014. Jakarta: Perpustakaan Nasional RI.

Nasution, S. (2008). Kurikulum dan Pengajaran. Bumi Aksara.

Patrick Howard, Charity Becker, Sean Wiebe, Mindy Carter, Peter Gouzouasis, Mitchell McLarnon, Pamela Richardson, Kathryn Ricketts \& Layal Schuman (2018) Creativity and pedagogical innovation: Exploring teachers' experiences of risk-taking, Journal of Curriculum Studies.

Peraturan Presiden Nomor 87 Tahun 2017 tentang Penguatan Pendidikan Karakter

Poerwati, .L.E. \& Amri, S. (2013). Panduan Memahami Kurikulum 2013. Prestasi Pustaka, Jakarta.

Sudjana, N. (2005). Pembinaan dan Pengembangan Kurikulum di Sekolah. Sinar Baru Algensindo.

Undang-Undang Republik Indonesia Nomor 20 Tahun 20013 tentang Sistem Pendidikan Nasional.

Waruwu, F.E. (2010). Membangun Budaya Berbasis Nilai. Kanisius Yogyakarta. 